It seems likely that the crystallized protein is identical with the starting material; a final identification cannot, however, be established without careful examination of other properties than the crystalline habit.

1 Hopkins, F. G., Nature, 126, 328 and 383 (1930).

2 Clark, J. H., J. Gen. Physiol., 27, 101 (1943), and 28, 539 (1943).

- Linderstrsm-Lang, K., Hotchkiss, R. D., and Johansen, G., Nature, 142, 996 (1938).

'Sørensen, S. P. L.., and Sørensen, M., C.R. Lab. Carlsberg, Ser. Chim. 23, 7, 86 (i939).

\section{THE NATURAL VEGETATION OF TRINIDAD}

$\lceil\mathrm{N}$ a work bearing this title*, Dr. J. S. Beard has 1 given a comprehensive and interesting account of the vegetation of the untouched forest regions of the island of Trinidad, B.W.I. In general, this work follows the earlier survey of R. C. Marshall and brings to the notice of the reader literature which has contributed to a knowledge of the ecology of this region. The underlying practical reason for this study, namely, the correct utilization and conservation of the remaining areas of unalienated Crown land, follows a long period of laisser-faire during which there was no effective official policy and when, as in many other tropical regions, the harmful utilization of virgin areas was all too common.

The present survey is both thorough and readable. It gives a clear account of the uniquely interesting position of Trinidad-an outlier of the South Ainerican continent, rather than the southernmost member of the Antilles-and of the factors which enter into the ecological situation. It might almost be said that if what you want is an adequate introduction to the vegetation of tropical America, you should begin with Trinidad. The advantages are numerous. The island, roughly about the size of an English county, has a rich flora (upwards of 2,200 angiosperms), many being representative of the mainland. On the whole this flora is now sufficiently well known, and herbaria are available for consultation. The data of considerable soil surveys are also available: no less than twenty-three types have been enumerated, which for ecological purposes can be classed into three groups in terms of drainage-a conception of which much use has been made in Beard's studies. Other relevant data, topographical, geological and meteorological, are also at hand and are summarized in the present work.

The total of endemic species in the entire flora is estimated at 7 per cent-a low figure for an island flora. The evident close affinity of the Trinidad flora is with the rich adjacent South American region; affinities of a more remote kind with the flora of West Africa can also be traced.

The present work is chiefly concerned with the tree flora. Although a considerable part of the original forested area has been cleared for cultivation, much still remains in its native state, the influence of man being entirely local in nature. A check list of trees is followed by a classification of the plant communities. The six formations which are recognized, seasonal, dry evergreen, montane, intermediate, swamp and marsh formations, are based on climatic and edaphic factors. Each is treated in detail and illustrated by diagrams and some good photographs. Space does

- Oxford Forestry Memoirs, No. 20, 1945. Pp. 152, with coloured map and 46 fllustrations. (Oxford : Clarendon Press, 1946.) not permit of any account being given of this con. siderable section of the memoir : the overall result is, however, excellent, and the reader, and still more the visiting botanist, will be able, in a short space of time, to gain a real insight into the components of this rich and varied region.

In the concluding section the author analyses and discusses the relationships observed and the ecological conceptions which emerge. In particular, he is concerned with the correct application of certain termsthe names of the several floristic groups-and with concepts such as the nature of the climax. Of the climatic climax he writes as follows :

"In the tropics, studies have shown repeatedly that it is the moisture-supplying ability of the soil which is the most important consideration and this is not necessarily at all closely concerned with climate. The writer's classification of the formations into six series is based entirely on moisture relations which result from the interplay of the three factors of climate, topography, and soil. The ecosystem, in fact, is one and indivisible. Climate, however, is the only component factor of the ecosystem which for any given area is constant (or presumably more or less constant). Land-form and soil, and with them the vegetation, pass through young, mature, and senile stages of development. Within any climatic region or zone, therefore, at some point in the cycle of development a formation will appear which can be interpreted as the highest type of vegetation which can develop under the given climate, other environ. mental factors (land-form, soil) having at the same time developed the most favourable moisture conditions possible to them in the cycle. The writer believes this to be a more workable definition of the climatic climax.

"As so defined, the climatic climax will not necess. arily be the highest type which can exist in the given climate, for such a type would only appear in the presence of ideally favourable conditions of soil and topography. This definition permits of the existence of more than one equivalent climatio climax within a given climate, according to differences in the land-form/soil complex."

A final section is devoted to a reconstruction of the palæo-ecology of the island. The author is to be congratulated on a valuable piece of work in which the reader's interest is sustained throughout.

\section{W. WARDLAW}

\section{TRAINING FOR CHEMISTS}

$T$ H.E Education Committee of the British Associa. tion of Chemists has recently published its suggestions on the education of chemists*, and though the report does not contain any strikingly novel proposals, it is full of sound sense and should be carefully studied in both academic and industrial chemical circles. The Committee points out that practically the whole of the industry of Britain is dependent on scientific control: a platitude, no doubt, to men of science, but a fact that still has to be emphasized, and emphasized repeatedly, for a general public to whom science is even yet an arcanum. To implement this control a steady and increasing flow of scientific men, and particularly chemists, is essential, and the Committee considers

- Education in Chemistry : the Teaching of Chemistry in Schools and the Training of (hemists and Chemical Technicians for Industry. (London : British Association of Chemists.) 2s. net. 